\title{
Sensitivity of Potato Cultivars to Potato mop-top virus-Induced Tuber Necrosis
}

\author{
O. Domfeh, F. G. Bittara, and N. C. Gudmestad Department of Plant Pathology, North Dakota State University, Fargo 58108
}

\begin{abstract}
Domfeh, O., Bittara, F. G., and Gudmestad, N. C. 2015. Sensitivity of potato cultivars to Potato mop-top virus-induced tuber necrosis. Plant Dis. 99: 788-796.

Potato (Solanum tuberosum) cultivars representing four market classes were assessed for sensitivity to Potato mop-top virus (PMTV)-induced tuber necrosis in three separate trials in a field in North Dakota known to be infested with PMTV. Reverse-transcription polymerase chain reaction confirmed the presence of PMTV in randomly selected samples. Results of tuber necrosis assessments conducted during storage demonstrated that sensitivity to PMTV-induced tuber necrosis among cultivars follows a continuum of tolerant to sensitive. As a group, the russet-skinned cultivars had a lower incidence of tuber necrosis than red-, yellow-, and white-skinned cultivars. The incidence and severity of PMTV-induced tuber necrosis in trial 1 were significantly correlated with those parameters in

trial 2 across years. Significant correlations also existed between the incidence of powdery scab on tubers and the incidence of PMTV-induced tuber necrosis in trial 1 across years. A significant correlation was also found between root gall numbers and powdery scab incidence and severity on tubers as well as PMTV-induced tuber necrosis incidence in trial 2. The results of this study provide growers with disease management options by avoiding cultivars highly sensitive to PMTV-induced tuber necrosis development and potentially replacing them with tolerant cultivars in the same market class. It is apparent from these studies that field assessments can be used for the development of PMTV-resistant germplasm for use in future breeding strategies.
\end{abstract}

The Potato mop-top virus (PMTV) causes serious economic losses in potato (Solanum tuberosum L.) production in affected countries $(33,40,47,49)$. PMTV, the type member of the genus Pomovirus $(29,57)$, is a rod-shaped, tripartite, single-stranded RNA virus $(33,50-52,56)$. PMTV has been reported in northern and central Europe, Asia, and North and South America $(2,7,23,24,26,27,31,32,38-40,45,62)$. In the United States, PMTV was first reported in Maine in 2003 (32), North Dakota in 2010 (16), Washington State in 2011 (14), Idaho in 2013 (61), and Colorado in 2014 (N. C. Gudmestad, unpublished).

PMTV is both seed- and soilborne. PMTV is vectored by Spongospora subterranea f. sp. subterranea $(4,7)$, the causal agent of powdery scab in potato. PMTV has been reported to remain infective in a field after 18 years without potato (6), surviving in the resting spores of $S$. subterranea f. sp. subterranea, which themselves are also long lived. This clearly indicates that, when PMTV is present in a field, it cannot be eliminated through normal or even prolonged periods of crop rotation. PMTV infection is partially systemic and only a proportion of the progeny tubers from an infected plant carry the infection $(8,15,30)$. This can lead to the elimination of the virus from potato crops after a few generations when the tubers are planted in soil free of PMTV and S. subterranea f. sp. subterranea $(6,15,30,56)$. Unlike its vector, PMTV has a narrow host range, infecting members of only three families: namely, Solanaceae, Tetragoniaceae, and Chenopodiaceae $(1,5,25)$. Humid soil and cool weather are conducive to PMTV because these conditions favor its vector $(12,21,58,60)$. The success of PMTV transmission by $S$. subterranea f. sp. subterranea has been reported to be greatest at 12 to $20^{\circ} \mathrm{C}$, while little or no infection occurs above $24^{\circ} \mathrm{C}(9)$.

Cultivar and environmental conditions greatly influence symptoms induced by PMTV $(12,20)$. Symptoms of primary infection include rust-colored lines, arcs, and rings on the surface of the tubers or internal brown arcs and flecks in the tuber flesh of sensitive cultivars $(7,21,31)$. In secondary infections, tubers may show reticulate or deep cracks, blotchy surface markings, or distortions $(7,21)$. The symptoms described above are similar to those induced by Tobacco rattle virus (TRV), both of which render affected tubers unmarketable.

Corresponding author: N. C. Gudmestad; E-mail: Neil.Gudmestad@ ndsu.edu Accepted for publication 30 November 2014.

http://dx.doi.org/10.1094/PDIS-07-14-0705-RE

(C) 2015 The American Phytopathological Society
The leaves of plants grown from infected tubers may show different shades of yellow markings which can easily be confused with leaf symptoms induced by Alfalfa mosaic virus and Potato aucuba mosaic virus (7). PMTV may cause shortening of internodes, which results in a dwarfed appearance (mop-top) (6). Virus-specific methods such as reverse-transcription polymerase chain reaction (RT-PCR), real-time RT-PCR, immunocapture RT-PCR, qualitative amplification based specific hybridization, RT-PCR-microplate hybridization, and enzymelinked immunosorbent assay (ELISA) have been used for the detection of PMTV in potato $(3,19,33,38,44,48,53,55)$. In the absence of suitable chemical treatments or other methods for effective control of $S$. subterranea f. sp. subterranea or PMTV, the most efficient measure for the prevention of this disease is avoidance; that is, to plant non-infected seed and avoid soils infested with virus-carrying $S$. subterranea $\mathrm{f}$. sp. subterranea (35). However, ensuring that only disease-free potato seed are planted is difficult to achieve because PMTV is currently not tested or evaluated under seed certification regulations in the United States (17). Thus, genetic resistance remains the best option for the management of this disease once it has been introduced into a field or onto a farm. Field trials have been conducted to assess the sensitivity of potato cultivars to PMTV-induced tuber necrosis in Europe $(6,11,31,39,40,46,47)$. Despite PMTV becoming more important in the United States, there has not been a detailed evaluation of potato cultivars for sensitivity to PMTV-induced tuber necrosis. The primary objective of this study was to screen some commonly grown U.S. potato cultivars for their reaction to tuber necrosis caused by PMTV to determine whether variability in symptom expression in tubers exists. To accomplish this, three cultivar trials were conducted in 2011,2012, and 2013 in a potato field in North Dakota known to be infested with PMTV-carrying $S$. subterranea f. sp. subterranea.

\section{Materials and Methods}

Cultivar trial 1. Fourteen potato cultivars, consisting of seven russet-, three white-, three red-, and one yellow-skinned market types (Table 1), were evaluated for sensitivity to PMTV-induced tuber necrosis in a randomized complete block design with four replications in 2011 and 2012. Each replication consisted of 15 seed tubers per cultivar planted $0.3 \mathrm{~m}$ apart with potato spacers ('Russet Burbank') planted between cultivars. The potato spacers between replications were used to provide continuous ground cover to decrease variability in soil moisture and soil temperature which can affect $S$. subterranea f. sp. subterranea infection $(58,60)$. 
Cultivar trial 2. Twenty-four cultivars of russet-, white-, red-, and yellow-skinned market types were planted in 2011 (Table 1). In 2012, due to unavailability of seed, 'Puren' and 'Patagonia' were not evaluated but five additional cultivars-'Dakota Crisp', 'Dakota Pearl', 'Colorado Rose', 'Alturas', and 'Atlantic'-were included. In both years, a randomized complete block design with three replications was used. Each replication consisted of 5 and 10 seed tubers per cultivar in 2011 and 2012, respectively, planted in rows $0.3 \mathrm{~m}$ apart. To ensure ground cover, seed tuber spacers (Russet Burbank) were planted between cultivars.

Cultivar trial 3. Five white-skinned potato cultivars in addition to a tolerant internal control ('Ivory Crisp'), previously included in trial 1 and trial 2 (Table 1), were evaluated for sensitivity to PMTV-induced tuber necrosis in a randomized complete block design with three replications in 2013. Each replication consisted of 10 seed tubers per cultivar planted $0.3 \mathrm{~m}$ apart. Seed tuber spacers (Russet Burbank) were planted between cultivars to ensure ground cover.

Seed tubers used in all trials were obtained from seed potato farms which were free of PMTV, as revealed by recent surveys. Each tuber was carefully examined during hand cutting to prepare seed for planting and none of them had $S$. subterranea f. sp. subterranea lesions or internal symptoms of tuber necrosis. All trials were conducted on a sandy loam soil. In 2011, the average air and soil temperatures of the experimental site during the growing season, as recorded by the North Dakota Agricultural Weather Network, were 18 and $19^{\circ} \mathrm{C}$, respectively. The amount of rainfall during the growing season totaled $355.6 \mathrm{~mm}$ while sprinkler irrigation amounted to $95.3 \mathrm{~mm}$. In 2012 , the average air and soil temperatures were 15.6 and $17^{\circ} \mathrm{C}$, respectively. A total of $518.2 \mathrm{~mm}$ of sprinkler irrigation was applied while rainfall amounted to $262.4 \mathrm{~mm}$. In 2013, the average air and soil temperatures were 18.9 and $19^{\circ} \mathrm{C}$, respectively. The amount of sprinkler irrigation applied was $355.6 \mathrm{~mm}$ while rainfall amounted to $176 \mathrm{~mm}$. The amount of nitrogen applied was $110 \mathrm{~kg} / \mathrm{ha}$ in
$2011,319 \mathrm{~kg} / \mathrm{ha}$ in 2012, and $333 \mathrm{~kg} / \mathrm{ha}$ in 2013. Each year, the herbicides pendimethalin and rimsulfuron were applied at the rates of 2.8 liters/ha and $105 \mathrm{~g} / \mathrm{ha}$, respectively. To control leafhoppers, green peach aphid, and Colorado potato beetles, insecticides such as thiamethoxam, imidachloprid, abamectin, and esfenvalerate were applied at rates recommended by manufacturers. Fungicides, including chlorothalonil, fluopyram/pyrimethanil, boscalid, and azoxystrobin, were applied to control early and late blight as appropriate for an irrigated commercial potato crop in the Upper Great Plains of the United States.

Root gall evaluation. Five plants were carefully removed 90 days after planting. Roots were gently shaken to release attached soil and galls were evaluated under a magnifying glass. Galls on roots were counted and expressed as number of galls per plant in accordance with the method used by Hernandez Maldonado (22). Data on root galls were collected for trials 1 and 2 in 2012 only.

Postharvest tuber sampling. After harvest, tubers were cured at a temperature of $10^{\circ} \mathrm{C}$ for 3 weeks and stored at 8 to $10^{\circ} \mathrm{C}$ thereafter. The tubers were evaluated three times for trial 1 and two times for trial 2 during storage for powdery scab infection on tubers and PMTV-induced tuber necrosis. For trial 1, evaluations were conducted 37, 117, and 204 days postharvest (DPH) in 2011 and 56, 167 , and 214 DPH in 2012. For trial 2, evaluations were done 70 and 136 DPH and 126 and 190 DPH in 2011 and 2012, respectively. Tubers were evaluated twice in trial 3 for PMTV-induced tuber necrosis at 63 and $133 \mathrm{DPH}$. For each trial, a sample consisting of 100 tubers per cultivar and replication was taken at random and one-third (trial 1) or half (trials 2 and 3 ) of the tubers were graded at each evaluation. All harvested tubers were used when less than 100 tubers were available. In trial 1, 15,636 and 26,181 tubers were examined in 2011 and 2012, respectively. The total number of tubers examined in trial 2 was 1,975 and 3,834 in 2011 and 2012, respectively, while 1,254 tubers were examined in trial 3 . This brings the total number of tubers evaluated for PMTV-induced tuber necrosis

Table 1. Potato cultivars evaluated in this study ${ }^{\mathrm{z}}$

\begin{tabular}{|c|c|c|c|c|c|c|c|c|c|}
\hline \multirow{2}{*}{$\frac{\text { Trial } 1}{\text { Cultivar }}$} & \multirow[b]{2}{*}{ Skin } & \multirow[b]{2}{*}{ Year } & \multirow{2}{*}{$\frac{\text { Trial } 2}{2011 \text { Cultivars }}$} & \multirow[b]{2}{*}{2012 Cultivars } & \multirow[b]{2}{*}{ Skin } & \multirow[b]{2}{*}{ Year } & \multicolumn{2}{|c|}{ Trial 32013} & \multirow[b]{2}{*}{ Year } \\
\hline & & & & & & & Cultivar & Skin & \\
\hline Russet Burbank & Russet & 1914 & Nicolet & Nicolet & White & 2012 & Nicolet & White & 2012 \\
\hline Russet Norkotah & Russet & 1987 & Alpine Russet & Alpine Russet & Russet & 2008 & Snowden & White & 1990 \\
\hline Ranger Russet & Russet & 1991 & Dakota Jewel & Dakota Jewel & Red & 2004 & Dakota Crisp & White & 2005 \\
\hline Umatilla Russet & Russet & 1998 & Yagana & Yagana & Yellow & 1983 & Atlantic & White & 1976 \\
\hline Alpine Russet & Russet & 2008 & Kennebec & Kennebec & White & 1948 & Ivory Crisp & White & 2002 \\
\hline Bannock Russet & Russet & 1999 & Dark Red Norland & Dark Red Norland & Red & 1957 & Lamoka & White & 2011 \\
\hline Dakota Trailblazer & Russet & 2009 & Puren & & Yellow & 1993 & $\ldots$ & $\ldots$ & $\ldots$ \\
\hline Ivory Crisp & White & 2002 & Snowden & Snowden & White & 1990 & $\ldots$ & $\ldots$ & $\ldots$ \\
\hline Shepody & White & 1980 & Viking & Viking & Red & 1963 & $\ldots$ & $\ldots$ & $\ldots$ \\
\hline Kennebec & White & 1948 & Red Pontiac & Red Pontiac & Red & 1945 & $\ldots$ & $\ldots$ & $\ldots$ \\
\hline Yukon Gold & Yellow & 1980 & Yukon Gold & Yukon Gold & Yellow & 1980 & $\ldots$ & $\ldots$ & $\ldots$ \\
\hline Red LaSoda & Red & 1953 & Red Norland & Red Norland & Red & 1964 & $\ldots$ & $\ldots$ & $\ldots$ \\
\hline Red Pontiac & Red & 1945 & Lamoka & Lamoka & White & 2011 & $\ldots$ & $\ldots$ & $\ldots$ \\
\hline Red Norland & Red & 1964 & Red LaSoda & Red LaSoda & Red & 1953 & $\ldots$ & $\ldots$ & $\ldots$ \\
\hline$\ldots$ & $\ldots$ & $\ldots$ & Patagonia & $\ldots$ & Red & 2009 & $\ldots$ & $\ldots$ & $\ldots$ \\
\hline$\ldots$ & $\ldots$ & $\ldots$ & Ivory Crisp & Ivory Crisp & White & 2002 & $\ldots$ & $\ldots$ & $\ldots$ \\
\hline$\ldots$ & $\ldots$ & $\ldots$ & Ranger Russet & Ranger Russet & Russet & 1991 & $\ldots$ & $\ldots$ & $\ldots$ \\
\hline$\ldots$ & $\ldots$ & $\ldots$ & Bannock Russet & Bannock Russet & Russet & 1999 & $\ldots$ & $\ldots$ & $\ldots$ \\
\hline$\ldots$ & $\ldots$ & $\ldots$ & Russet Burbank & Russet Burbank & Russet & 1914 & $\ldots$ & $\ldots$ & $\ldots$ \\
\hline$\ldots$ & $\ldots$ & $\ldots$ & Karu & Karu & Red & 2002 & $\ldots$ & $\ldots$ & $\ldots$ \\
\hline$\ldots$ & $\ldots$ & $\ldots$ & Umatilla Russet & Umatilla Russet & Russet & 1998 & $\ldots$ & $\ldots$ & $\ldots$ \\
\hline$\ldots$ & $\ldots$ & $\ldots$ & Russet Norkotah & Russet Norkotah & Russet & 1987 & $\ldots$ & $\ldots$ & $\ldots$ \\
\hline$\ldots$ & $\ldots$ & $\ldots$ & Shepody & Shepody & White & 1980 & $\ldots$ & $\ldots$ & $\ldots$ \\
\hline$\ldots$ & $\ldots$ & $\ldots$ & Dakota Trailblazer & Dakota Trailblazer & Russet & 2009 & $\ldots$ & $\ldots$ & $\ldots$ \\
\hline$\ldots$ & $\ldots$ & $\ldots$ & $\ldots$ & Dakota Crisp & White & 2005 & $\ldots$ & $\cdots$ & $\ldots$ \\
\hline$\ldots$ & $\ldots$ & $\ldots$ & $\ldots$ & Dakota Pearl & White & 1999 & $\ldots$ & $\ldots$ & $\ldots$ \\
\hline$\ldots$ & $\ldots$ & $\ldots$ & $\ldots$ & Colorado Rose & Red & 2000 & $\ldots$ & $\ldots$ & $\ldots$ \\
\hline$\ldots$ & $\ldots$ & $\ldots$ & $\ldots$ & Alturas & Russet & 2002 & $\ldots$ & $\ldots$ & $\ldots$ \\
\hline$\ldots$ & $\ldots$ & $\ldots$ & $\ldots$ & Atlantic & White & 1976 & $\ldots$ & $\ldots$ & $\ldots$ \\
\hline
\end{tabular}

${ }^{\mathrm{z}}$ The same 14 potato cultivars were planted in 2011 and 2012 for trial 1 . Skin $=$ skin color and Year $=$ year of release. 
in this study to 48,880 . PMTV incidence and severity index were determined using previously published protocols (40). Washed tubers were cut lengthwise into 1-cm-thick slices with a SafeHands Professional Mandolin slicer (Jaccard Corporation, NY). PMTV incidence was calculated as the number of tubers showing symptoms of PMTV-induced necrosis per the total number of tubers examined for each sample. The number of slices per tuber with internal necrosis was determined $(a)$. The slice with the most severe necrosis was then covered with a mask of 1-cm-broad strips and the number of strips with necrosis was recorded $(b)$. An index of PMTV severity was calculated by multiplying the two measurements $(a \times b)$ and expressing the values between 0 and 1 , where 0 indicates no necrosis and 1 indicates the presence of necrosis throughout the tuber. Cultivars were ranked based on the overall incidence means of tuber necrosis according to the following categorization: tolerant $=<5 \%$, moderately tolerant $=>5$ to $10 \%$, moderately sensitive $=>10$ to $15 \%$, and sensitive $=>15 \%$. The overall incidence was calculated by adding the incidence of each cultivar for 2011 to that of 2012. Only cultivars planted in 2011 and 2012 were included in the classification.

Powdery scab on tubers was visually assessed and severity scored by comparing the area of tuber covered by disease with a modified graphic scale (18). An average percentage of the sample disease severity was calculated. Symptoms were confirmed by observation of cystosori under the microscope $(\times 400)$ when required. Incidence was obtained by calculating the percentage of symptomatic tubers from the total number of tubers in the sample.

Detection of PMTV and TRV. Necrotic tissues were taken from slices of potato tubers with a sharp scalpel sterilized in $75 \%$ ethanol and flamed until red-hot between samples. The tissues were crushed in liquid nitrogen and stored at $-80^{\circ} \mathrm{C}$ until used for RNA extraction. Total RNA was extracted using TRIzol reagent (Life Technologies,

Table 2. Mean number of Spongospora galls per plant on potato roots 90 days after planting in trials 1 and $2(2012 \text { only })^{\mathrm{z}}$

\begin{tabular}{|c|c|c|c|}
\hline \multicolumn{2}{|c|}{ Trial 1} & \multicolumn{2}{|c|}{ Trial 2} \\
\hline Cultivar & Galls & Cultivar & Galls \\
\hline Kennebec & $110.3 \mathrm{a}$ & Lamoka & $149.6 \mathrm{a}$ \\
\hline Red Pontiac & $65.0 \mathrm{~b}$ & Kennebec & $115.3 \mathrm{ab}$ \\
\hline Umatilla Russet & $46.3 \mathrm{bc}$ & Red Pontiac & $77.8 \mathrm{bc}$ \\
\hline Red Norland & $38.0 \mathrm{bcd}$ & Snowden & $76.0 \mathrm{bc}$ \\
\hline Ivory Crisp & $36.6 \mathrm{cde}$ & Shepody & $64.2 \mathrm{bcd}$ \\
\hline Shepody & $26.1 \mathrm{def}$ & Nicolet & $43.7 \mathrm{~cd}$ \\
\hline Russet Burbank & 14.8 efg & Red LaSoda & $32.6 \mathrm{~cd}$ \\
\hline Red LaSoda & $12.5 \mathrm{fgh}$ & Umatilla Russet & $26.3 \mathrm{~cd}$ \\
\hline Alpine Russet & 10.0 fghi & Yagana & $25.1 \mathrm{~cd}$ \\
\hline Ranger Russet & 3.4 ghij & Alpine Russet & $22.4 \mathrm{~cd}$ \\
\hline Dakota Trailblazer & 2.5 ghij & Dakota Pearl & $16.2 \mathrm{~cd}$ \\
\hline Yukon Gold & $2.3 \mathrm{hij}$ & Russet Burbank & $12.9 \mathrm{~cd}$ \\
\hline Bannock Russet & $1.7 \mathrm{ij}$ & Colorado Rose & $12.2 \mathrm{~cd}$ \\
\hline Russet Norkotah & $0.8 \mathrm{j}$ & Ivory Crisp & $12.1 \mathrm{~cd}$ \\
\hline$\ldots$ & $\ldots$ & Viking & $11.9 \mathrm{~cd}$ \\
\hline$\cdots$ & $\cdots$ & Dark Red Norland & $10.0 \mathrm{~d}$ \\
\hline$\ldots$ & $\ldots$ & Alturas & $9.5 \mathrm{~d}$ \\
\hline$\ldots$ & $\ldots$ & Atlantic & $9.1 \mathrm{~d}$ \\
\hline$\ldots$ & $\ldots$ & Yukon Gold & $8.5 \mathrm{~d}$ \\
\hline$\ldots$ & $\ldots$ & Bannock Russet & $8.1 \mathrm{~d}$ \\
\hline$\ldots$ & $\ldots$ & Red Norland & $6.3 \mathrm{~d}$ \\
\hline$\ldots$ & $\ldots$ & Ranger Russet & $5.8 \mathrm{~d}$ \\
\hline$\ldots$ & $\ldots$ & Dakota Crisp & $5.6 \mathrm{~d}$ \\
\hline$\ldots$ & $\ldots$ & Dakota Trailblazer & $4.1 \mathrm{~d}$ \\
\hline$\ldots$ & $\ldots$ & Karu & $3.5 \mathrm{~d}$ \\
\hline$\cdots$ & $\cdots$ & Russet Norkotah & $3.4 \mathrm{~d}$ \\
\hline$\ldots$ & $\ldots$ & Dakota Jewel & $3.2 \mathrm{~d}$ \\
\hline $\left.\operatorname{LSD}_{(P}=0.05\right)$ & 25.8 & $\ldots$ & 66.0 \\
\hline
\end{tabular}

$\mathrm{z}^{\mathrm{z}}$ Galls $=$ mean number of root galls. Means with the same letter are not significantly different based on Fisher's protected least significant difference (LSD) $(P=0 \cdot 05)$. Root gall numbers were square root transformed prior to analysis. Reported means are based on the untransformed data.
Grand Island, NY) according to the manufacturer's instructions, with the exception that $0.8 \mathrm{ml}$ was added to each tube for tissue homogenization instead of $1 \mathrm{ml}$. The RNA pellets were air dried for 5 to $10 \mathrm{~min}$ and, thereafter, the pellets were dissolved in $100 \mu \mathrm{l}$ of RNase-free water. Detection of PMTV in tubers was done by RTPCR according to a previously published protocol (38), with the only modification being the use of $0.2 \mu \mathrm{l}$ of random primers $(500 \mu \mathrm{g} / \mathrm{ml})$ and $3.3 \mu \mathrm{l}$ of RNase-free water instead of 1 and $2.5 \mu \mathrm{l}$, respectively. To further demonstrate that tuber necrosis was caused by PMTV, RNA from tuber extractions were also tested for TRV using RTPCR according to Robinson (43). For trials 1 and 2, 150 and 200 randomly selected symptomatic tubers were tested for PMTV and TRV in 2011 and 2012, respectively, while 50 tubers were tested for trial 3.

Statistical analysis. Statistical analyses of the experimental data were carried out using the Statistical Analysis Software, version 9.3. Separate analyses of variance (ANOVA) were conducted on the percentage of data for incidence and severity of powdery scab and PMTV-induced tuber necrosis for each year due to nonhomogeneity of variance between years (Levene's test: $P<0.000)(36)$. In each trial, combined ANOVA analyses were carried out for data evaluated two or three times during storage because variances across evaluation periods were homogeneous (36). Residual plots of the percentage data sets (PMTV-induced tuber necrosis and powdery scab on tubers) as well as root gall data for trial 2 revealed that ANOVA could be performed without prior transformation because major assumptions were satisfied. Root gall number for trial 1 was square root transformed prior to ANOVA. Treatments were compared using the Fisher's protected least significant difference test at $P \leq 0.05$. The Pearson's correlation coefficient was calculated to demonstrate the degree of association between parameters. The calculation of correlations between trials involved the 14 cultivars common to trials 1 and 2 over a 2 -year period.

\section{Results}

Susceptibility of potato cultivars to powdery scab infection. In trials 1 and 2, cultivars differed significantly $(P<0.0001)$ in susceptibility to root gall formation caused by $S$. subterranea f. sp. subterranea. In trial 1, the mean number of galls per plant ranged from 0.8 in 'Russet Norkotah' to 110.3 in 'Kennebec' (Table 2). 'Kennebec', 'Red Pontiac', 'Umatilla Russet', 'Red Norland', Ivory Crisp, and 'Shepody' were among the most susceptible cultivars while Russet Norkotah, 'Bannock Russet', and 'Yukon Gold' were among the least affected. In trial 2, the mean number of galls per plant ranged from 3.2 in 'Dakota Jewel' to 149.6 in 'Lamoka' (Table 2). Root gall formation was most severe in Lamoka, Kennebec, Red Pontiac, 'Snowden', and Shepody while Dakota Jewel, Russet Norkotah, 'Karu', 'Dakota Trailblazer', and Dakota Crisp were among the least affected.

In trials 1 and 2, powdery scab lesion incidence and severity on tubers differed significantly $(P<0.0001)$ in 2011 and 2012. In trial 1 , the incidence of powdery scab lesions on tubers across cultivars was 0 to $47.5 \%$ while severity was 0 to $2.9 \%$ in 2011 (Table 3). In 2012, powdery scab lesion incidence on tubers was 0 to $57 \%$ while severity was 0 to $2.7 \%$ (Table 3 ). Powdery scab incidence and severity were highest in Shepody, 'Red LaSoda', Kennebec, and Ivory Crisp across years. As expected, powdery scab incidence and severity were lowest in the russet-skinned cultivars across years. Russet Norkotah and Bannock Russet did not have powdery scab lesions on tubers in 2011, as was observed in 'Alpine Russet' and Umatilla Russet in 2012. In trial 2, the incidence of powdery scab lesions on tubers ranged from $0 \%$ in several russet-skinned cultivars to $50.8 \%$ in Kennebec while severity was 0 to $0.7 \%$ in 2011 (Table 4). Kennebec, Shepody, Red LaSoda, and 'Viking' were among the cultivars with the highest incidence while Alpine Russet, 'Ranger Russet', Bannock Russet, Russet Burbank, Russet Norkotah, Umatilla Russet, and Dakota Trailblazer had no powdery scab lesions on tubers. In 2012, the incidence of powdery scab on tubers was 0 to $52.8 \%$ while severity was 0 to $3.5 \%$ (Table 4 ). Kennebec, Red LaSoda, Dakota Pearl, Shepody, and Red Pontiac were among the cultivars most susceptible to powdery scab lesion on tubers while Bannock 
Russet, Russet Burbank, Umatilla Russet, and Dakota Trailblazer did not have lesions.

Sensitivity of potato cultivars to PMTV-induced tuber necrosis. Cultivar trial 1. PMTV-induced tuber necrosis incidence and severity differed significantly among cultivars $(P<0.0001)$ in both years. In
2011, incidence ranged from 0\% in Bannock Russet to 5.2\% in Red Norland, while severity indices ranged from 0 in Bannock Russet to over 0.1 in Red Norland (Table 5). In 2012, the incidence of PMTV-induced tuber necrosis ranged from over $0.3 \%$ in Bannock Russet to $17 \%$ in Red LaSoda while severity indices ranged from

Table 3. Mean incidence and severity of powdery scab caused by Spongospora subterranea f. sp. subterranea in 14 potato cultivars planted in 2011 and 2012 and evaluated three times during a 7-month storage period (trial 1$)^{\mathrm{z}}$

\begin{tabular}{|c|c|c|c|c|}
\hline \multirow[b]{3}{*}{ Cultivar } & \multicolumn{4}{|c|}{ Powdery scab on tubers } \\
\hline & \multicolumn{2}{|c|}{2011} & \multicolumn{2}{|c|}{2012} \\
\hline & Incidence (\%) & Severity $(\%)$ & Incidence (\%) & $\overline{\text { Severity }(\%)}$ \\
\hline Shepody & $47.5 \mathrm{a}$ & $2.9 \mathrm{a}$ & $50.6 \mathrm{a}$ & $1.3 \mathrm{bc}$ \\
\hline Red LaSoda & $43.1 \mathrm{ab}$ & $1.4 \mathrm{~b}$ & $57.0 \mathrm{a}$ & $2.7 \mathrm{a}$ \\
\hline Kennebec & $37.7 \mathrm{bc}$ & $1.5 \mathrm{~b}$ & $55.7 \mathrm{a}$ & $1.5 \mathrm{~b}$ \\
\hline Ivory Crisp & $32.4 \mathrm{~cd}$ & $0.7 \mathrm{c}$ & $27.8 \mathrm{~b}$ & $0.4 \mathrm{bcd}$ \\
\hline Red Pontiac & $29.1 \mathrm{~d}$ & $0.8 \mathrm{c}$ & $17.1 \mathrm{bcd}$ & $0.2 \mathrm{~cd}$ \\
\hline Red Norland & $16.3 \mathrm{e}$ & $0.2 \mathrm{~cd}$ & $21.9 \mathrm{bc}$ & $0.2 \mathrm{~cd}$ \\
\hline Yukon Gold & $14.4 \mathrm{e}$ & $0.1 \mathrm{~d}$ & 8.6 cde & $0.1 \mathrm{~d}$ \\
\hline Ranger Russet & $1.3 \mathrm{f}$ & $>0.0 * \mathrm{~d}$ & $1.3 \mathrm{de}$ & $>0.0 * \mathrm{~d}$ \\
\hline Russet Burbank & $0.6 \mathrm{f}$ & $>0.0^{*} \mathrm{~d}$ & $0.3 \mathrm{e}$ & $>0.0 * \mathrm{~d}$ \\
\hline Alpine Russet & $0.2 \mathrm{f}$ & $>0.0^{*} \mathrm{~d}$ & $0.0 \mathrm{e}$ & $0.0 \mathrm{~d}$ \\
\hline Umatilla Russet & $0.2 \mathrm{f}$ & $>0.0 * \mathrm{~d}$ & $0.0 \mathrm{e}$ & $0.0 \mathrm{~d}$ \\
\hline Dakota Trailblazer & $0.2 \mathrm{f}$ & $>0.0 * \mathrm{~d}$ & $2.8 \mathrm{de}$ & $>0.0 * \mathrm{~d}$ \\
\hline Russet Norkotah & $0.0 \mathrm{f}$ & $0.0 \mathrm{~d}$ & $0.9 \mathrm{e}$ & $>0.0 * \mathrm{~d}$ \\
\hline Bannock Russet & $0.0 \mathrm{f}$ & $0.0 \mathrm{~d}$ & $0.9 \mathrm{e}$ & $>0.0 * \mathrm{~d}$ \\
\hline $\operatorname{LSD}_{(P=0.05)}$ & 7.8 & 0.6 & 15.9 & 1.1 \\
\hline
\end{tabular}

${ }^{\mathbf{z}}$ Means with the same letter are not significantly different based on Fisher's protected least significant difference (LSD) $(P=0 \cdot 05)$. An asterisk (*) indicates that severity of powdery scab is not a true zero because there were a few tubers with powdery scab lesions.

Table 4. Mean incidence and severity of powdery scab caused by Spongospora subterranea f. sp. subterranea in potato cultivars planted in 2011 and 2012 and evaluated twice during storage (trial 2)

\begin{tabular}{|c|c|c|c|c|}
\hline \multirow[b]{3}{*}{ Cultivar } & \multicolumn{4}{|c|}{ Powdery scab on tubers } \\
\hline & \multicolumn{2}{|c|}{2011} & \multicolumn{2}{|c|}{2012} \\
\hline & Incidence (\%) & Severity (\%) & Incidence (\%) & Severity $(\%)$ \\
\hline Kennebec & $50.8 \mathrm{a}$ & $0.7 \mathrm{a}$ & $52.8 \mathrm{a}$ & $3.5 \mathrm{a}$ \\
\hline Shepody & $24.1 \mathrm{~b}$ & $0.2 \mathrm{bcd}$ & $35.1 \mathrm{~b}$ & $1.5 \mathrm{c}$ \\
\hline Red LaSoda & $21.8 \mathrm{bc}$ & $0.2 \mathrm{bc}$ & $51.4 \mathrm{a}$ & $2.6 \mathrm{~b}$ \\
\hline Viking & $20.4 \mathrm{bcd}$ & $0.3 \mathrm{~b}$ & $21.5 \mathrm{~cd}$ & 0.3 ef \\
\hline Lamoka & $14.1 \mathrm{bcde}$ & $0.1 \mathrm{bcd}$ & 16.5 cdef & 0.2 ef \\
\hline Yukon Gold & 13.0 bcdef & $0.2 \mathrm{bcd}$ & $7.1 \mathrm{fgh}$ & $0.1 \mathrm{f}$ \\
\hline Ivory Crisp & 13.0 bcdef & $0.1 \mathrm{~cd}$ & $27.3 \mathrm{bc}$ & 0.8 cde \\
\hline Puren & 9.4 cdefg & $>0.0 * \mathrm{~cd}$ & $\ldots$ & $\ldots$ \\
\hline Dakota Jewel & 9.0 defg & $0.1 \mathrm{bcd}$ & $6.2 \mathrm{fgh}$ & $0.1 \mathrm{f}$ \\
\hline Red Pontiac & $7.4 \mathrm{efg}$ & $0.1 \mathrm{~cd}$ & $37.0 \mathrm{~b}$ & $1.1 \mathrm{~cd}$ \\
\hline Yagana & $6.4 \mathrm{efg}$ & $>0.0 * \mathrm{~cd}$ & $6.4 \mathrm{fgh}$ & $>0.0 * \mathrm{f}$ \\
\hline Dark Red Norland & $4.3 \mathrm{efg}$ & $0.1 \mathrm{bcd}$ & $9.4 \mathrm{efgh}$ & $0.0 \mathrm{f}$ \\
\hline Nicolet & $3.1 \mathrm{efg}$ & $>0.0 * \mathrm{~d}$ & $16.7 \mathrm{cdef}$ & 0.2 ef \\
\hline Red Norland & $3.0 \mathrm{efg}$ & $>0.0 * \mathrm{~d}$ & 20.7 cde & $0.5 \mathrm{def}$ \\
\hline Karu & $1.3 \mathrm{gf}$ & $>0.0 * \mathrm{~d}$ & $3.6 \mathrm{gh}$ & $>0.0 * \mathrm{f}$ \\
\hline Patagonia & $1.0 \mathrm{gf}$ & $>0.0^{*} \mathrm{~d}$ & $\ldots$ & $\ldots$ \\
\hline Snowden & $0.6 \mathrm{gf}$ & $>0.0 * \mathrm{~d}$ & $4.1 \mathrm{gh}$ & $>0.0 * \mathrm{f}$ \\
\hline Alpine Russet & $0.0 \mathrm{~g}$ & $0.0 \mathrm{~d}$ & $0.7 \mathrm{~h}$ & $>0.0 * \mathrm{f}$ \\
\hline Ranger Russet & $0.0 \mathrm{~g}$ & $0.0 \mathrm{~d}$ & $0.6 \mathrm{~h}$ & $>0.0 * \mathrm{f}$ \\
\hline Bannock Russet & $0.0 \mathrm{~g}$ & $0.0 \mathrm{~d}$ & $0.0 \mathrm{~h}$ & $0.0 \mathrm{f}$ \\
\hline Russet Burbank & $0.0 \mathrm{~g}$ & $0.0 \mathrm{~d}$ & $0.0 \mathrm{~h}$ & $0.0 \mathrm{f}$ \\
\hline Russet Norkotah & $0.0 \mathrm{~g}$ & $0.0 \mathrm{~d}$ & $1.1 \mathrm{~h}$ & $>0.0 * \mathrm{f}$ \\
\hline Umatilla Russet & $0.0 \mathrm{~g}$ & $0.0 \mathrm{~d}$ & $0.0 \mathrm{~h}$ & $0.0 \mathrm{f}$ \\
\hline Dakota Trailblazer & $0.0 \mathrm{~g}$ & $0.0 \mathrm{~d}$ & $0.0 \mathrm{~h}$ & $0.0 \mathrm{f}$ \\
\hline Dakota Pearl & $\ldots$ & $\ldots$ & $50.7 \mathrm{a}$ & $1.4 \mathrm{c}$ \\
\hline Dakota Crisp & $\ldots$ & $\ldots$ & 20.4 cde & $0.4 \mathrm{def}$ \\
\hline Colorado Rose & $\ldots$ & $\ldots$ & $13.9 \mathrm{defg}$ & 0.3 ef \\
\hline Atlantic & $\ldots$ & $\ldots$ & $5.6 \mathrm{fgh}$ & $>0.0 * \mathrm{f}$ \\
\hline Alturas & $\ldots$ & $\ldots$ & $1.0 \mathrm{~h}$ & $>0.0 * \mathrm{f}$ \\
\hline $\left.\operatorname{LSD}_{(P}=0.05\right)$ & 12.5 & 0.2 & 12.1 & 0.7 \\
\hline
\end{tabular}

${ }^{\mathrm{z}}$ Means with the same letter are not significantly different based on Fisher's protected least significant difference (LSD) $(P=0 \cdot 05)$. An asterisk $(*)$ indicates that severity of powdery scab is not a true zero because there were a few tubers with powdery scab lesions. 
0.002 in Bannock Russet to 0.14 in Red Pontiac (Table 5). There was a highly significant correlation between PMTV-induced tuber necrosis incidence and severity among cultivars in $2011(r=0.97, P=0.001)$ and $2012(r=0.66, P=0.01)$. The overall correlation between incidence and severity among cultivars across years was also significant $(r=0.79, P=0.001)$. This means that cultivars with the highest incidence of PMTV-induced tuber necrosis also had the highest severity of the disease. Based on the 2-year results of PMTV-induced tuber necrosis incidence, the cultivars can be ranked as follows: tolerant $=$ Bannock Russet, Dakota Trailblazer, Yukon Gold, Ivory Crisp, and Umatilla Russet (overall incidence of $<5 \%$ ); moderately tolerant = Ranger Russet, Alpine Russet, Russet Burbank, Red Pontiac, Russet Norkotah, and Shepody (overall incidence of $>5$ to $10 \%$ ); moderately sensitive $=$ Kennebec ( $13.8 \%$ overall incidence); and sensitive $=$ Red Norland and Red LaSoda (overall incidence of 17.6 and $18.6 \%$, respectively) (Table 6).

In 2011 and 2012, PMTV-induced tuber necrosis incidence increased significantly during storage $(P<0.0001)$. A significant interaction $(P<0.0001)$ was found between period of evaluation and cultivar in PMTV-induced tuber necrosis incidence. Generally, more PMTV-induced tuber necrosis symptoms were found in the second and third evaluations than the first. The highest increase in incidence occurred in Kennebec, Red Norland, Red LaSoda, Red Pontiac, and Shepody but remained unchanged in several cultivars. However, the severity of PMTV-induced tuber necrosis did not change during storage in $2011(P>0.47)$ but increased significantly $(P<0.0001)$ in 2012, with the highest increase occurring in Kennebec, Ranger Russet, Red LaSoda, Russet Norkotah, Red Norland, and Russet Burbank. The presence of PMTV was readily confirmed in randomly selected symptomatic tubers by RT-PCR. TRV was not detected in any of tubers tested.

Cultivar trial 2. As with trial 1, the incidence of PMTV-induced tuber necrosis was low among cultivars in 2011; therefore, differences in incidence and severity were not statistically significant among cultivars (Table 7). However, in 2012, differences among cultivars in PMTVinduced tuber incidence and severity were highly significant $(P<$ 0.0001). PMTV-induced tuber necrosis incidence ranged from $0 \%$ in Bannock Russet to $29.9 \%$ in Dakota Crisp while severity indices ranged from 0 in Bannock Russet to 0.49 in Lamoka (Table 7). Cultivars such as Dakota Jewel, Dakota Crisp, and 'Dark Red Norland' had significantly higher PMTV-induced necrosis incidence than both Red Norland and Red LaSoda while Bannock Russet, Umatilla Russet, Ivory Crisp, Russet Norkotah, Yukon Gold, and 'Nicolet' were among those least sensitive. There was no correlation between PMTV-induced tuber necrosis incidence and severity among cultivars in $2011(r=0.24$ $P=0.20)$ and $2012(r=0.49, P=0.10)$. However, the incidence of PMTV-induced tuber necrosis was significantly correlated with severity among cultivars across years $(r=0.53, P=0.05)$. Based on the 2year results of PMTV tuber necrosis incidence, the cultivars can be ranked as follows: tolerant $=$ Bannock Russet, Dakota Trailblazer, Russet Norkotah, Umatilla Russet, Yukon Gold, Ivory Crisp, Russet Burbank, Karu, and Shepody (overall incidence of $<5 \%$ ); moderately tolerant $=$ Viking, Red Pontiac, Red Norland, and Ranger Russet (overall incidence of $>5$ to $10 \%$ ); moderately sensitive $=$ Nicolet, Kennebec, and Red LaSoda (overall incidence of $>10$ to $15 \%$ ); and sensitive $=$ Alpine Russet, Snowden, Lamoka, Dakota Jewel, Dark Red Norland, and 'Yagana' (overall incidence of $>15 \%$ ) (Table 6).

Table 5. Mean incidence and severity index of Potato mop-top virus (PMTV)-induced tuber necrosis in 14 potato cultivars planted in 2011 and 2012 and evaluated three times during a 7 -month storage period (trial 1$)^{\mathrm{z}}$

\begin{tabular}{|c|c|c|c|c|}
\hline \multirow[b]{3}{*}{ Cultivar } & \multicolumn{4}{|c|}{ PMTV tuber necrosis } \\
\hline & \multicolumn{2}{|c|}{2011} & \multicolumn{2}{|c|}{2012} \\
\hline & Incidence (\%) & Severity index & Incidence (\%) & Severity index \\
\hline Red Norland & $5.2 \mathrm{a}$ & $0.10 \mathrm{a}$ & $12.4 \mathrm{~b}$ & $0.10 \mathrm{bd}$ \\
\hline Red LaSoda & $1.7 \mathrm{~b}$ & $0.03 \mathrm{~b}$ & $17.0 \mathrm{a}$ & $0.11 \mathrm{abc}$ \\
\hline Ranger Russet & $0.9 \mathrm{bc}$ & $>0.0 * \mathrm{bc}$ & $6.4 \mathrm{~d}$ & $0.11 \mathrm{ab}$ \\
\hline Alpine Russet & $0.5 \mathrm{bc}$ & $0.01 \mathrm{bc}$ & $5.5 \mathrm{de}$ & $0.11 \mathrm{abc}$ \\
\hline Kennebec & $0.7 \mathrm{bc}$ & $>0.0 * \mathrm{c}$ & $13.2 \mathrm{~b}$ & $0.05 \mathrm{de}$ \\
\hline Yukon Gold & $0.7 \mathrm{bc}$ & $>0.0 * \mathrm{c}$ & $4.0 \mathrm{df}$ & $0.03 \mathrm{eg}$ \\
\hline Russet Burbank & $0.4 \mathrm{bc}$ & $>0.0 * \mathrm{bc}$ & $4.7 \mathrm{df}$ & $0.05 \mathrm{def}$ \\
\hline Ivory Crisp & $0.4 \mathrm{bc}$ & $0.01 \mathrm{bc}$ & $2.9 \mathrm{efg}$ & $0.05 \mathrm{def}$ \\
\hline Red Pontiac & $0.4 \mathrm{bc}$ & $0.02 \mathrm{bc}$ & $9.4 \mathrm{c}$ & $0.14 \mathrm{a}$ \\
\hline Russet Norkotah & $0.4 \mathrm{bc}$ & $>0.00 * \mathrm{c}$ & $5.7 \mathrm{~d}$ & 0.06 cde \\
\hline Dakota Trailblazer & $0.2 \mathrm{c}$ & $>0.00 * \mathrm{bc}$ & $0.5 \mathrm{~g}$ & $>0.00 * \mathrm{fg}$ \\
\hline Umatilla Russet & $0.1 \mathrm{c}$ & $>0.00 * \mathrm{c}$ & $2.3 \mathrm{fg}$ & $0.02 \mathrm{eg}$ \\
\hline Shepody & $0.1 \mathrm{c}$ & $>0.00 * \mathrm{bc}$ & $6.3 \mathrm{~d}$ & $0.04 \mathrm{eg}$ \\
\hline Bannock Russet & $0.0 \mathrm{c}$ & $0.00 \mathrm{c}$ & $0.3 \mathrm{~g}$ & $>0.00 * \mathrm{~g}$ \\
\hline $\mathrm{LSD}_{(\mathrm{P}=0.05)}$ & 1.41 & 0.03 & 2.68 & 0.05 \\
\hline
\end{tabular}

${ }^{\mathrm{z}}$ Means with the same letter are not significantly different based on Fisher's protected least significant difference (LSD) $(P=0 \cdot 05)$. Index is given as a value between 0 and 1 , where 0 indicates no tuber necrosis and 1 presence of necrosis through the tuber. An asterisk $(*)$ indicates that severity of PMTV-induced tuber necrosis is not a true zero because there were a few tubers with internal necrosis.

Table 6. Summary of sensitivity rankings of potato cultivars based on Potato mop-top virus (PMTV)-induced tuber necrosis incidence values summed for 2011 and 2012

\begin{tabular}{|c|c|c|c|c|}
\hline Trial & $\begin{array}{c}\text { Tolerant cultivars } \\
\text { (overall incidence }<\mathbf{5 \%} \text { ) }\end{array}$ & $\begin{array}{l}\text { Moderately tolerant cultivars } \\
\text { (overall incidence }>5 \text { to } 10 \% \text { ) }\end{array}$ & $\begin{array}{c}\text { Moderately sensitive } \\
\text { cultivars (overall } \\
\text { incidence }>10 \text { to } 15 \%)\end{array}$ & $\begin{array}{c}\text { Sensitive cultivars } \\
\text { (Overall incidence }>15 \%)\end{array}$ \\
\hline Trial 1 & $\begin{array}{l}\text { Bannock Russet, Dakota } \\
\text { Trailblazer, Yukon Gold, } \\
\text { Ivory Crisp and Umatilla } \\
\text { Russet }\end{array}$ & $\begin{array}{l}\text { Ranger Russet, Alpine Russet, Russet } \\
\text { Burbank, Red Pontiac, Russet } \\
\text { Norkotah and Shepody }\end{array}$ & Kennebec & Red Norland and Red LaSoda \\
\hline Trial 2 & $\begin{array}{l}\text { Bannock Russet, Dakota } \\
\text { Trailblazer, Russet Norkotah, } \\
\text { Umatilla Russet, Yukon Gold, } \\
\text { Ivory Crisp, Russet Burbank, } \\
\text { Karu and Shepody }\end{array}$ & $\begin{array}{l}\text { Viking, Red Pontiac, Red Norland } \\
\text { and Ranger Russet }\end{array}$ & $\begin{array}{l}\text { Nicolet, Kennebec and } \\
\text { Red LaSoda }\end{array}$ & $\begin{array}{l}\text { Alpine Russet, Snowden, Lamoka, } \\
\text { Dakota Jewel, Dark Red Norland } \\
\text { and Yagana }\end{array}$ \\
\hline
\end{tabular}


In 2011, PMTV-induced tuber necrosis incidence increased significantly $(P<0.0001)$ during storage. As noted in cultivar trial 1 , a significant interaction $(P<0.0002)$ was found between time of evaluation and cultivar in PMTV tuber necrosis incidence. Generally, incidence was higher in the second evaluation than the first and cultivars such as Alpine Russet, Dakota Jewel, Kennebec, Nicolet, Puren, and Yagana had the highest increase. The severity of PMTV tuber necrosis did not change during storage $(P>0.17)$. In 2012, changes in PMTV tuber necrosis incidence $(P>0.28)$ and severity $(P>0.67)$ during storage were not significant. However, a significant interaction was found between the time of evaluation and cultivar $(P=0.02)$ in PMTV tuber necrosis incidence. A large decrease in incidence $(25.8 \%)$ was observed in Dakota Jewel between the first and second evaluations but incidence increased in a number of cultivars such as Snowden, Red LaSoda, Alpine Russet, Red Norland, and Dark Red Norland during the same period. Presence of PMTV was confirmed in randomly selected symptomatic tubers by RT-PCR, and TRV was not detected in any of the tubers tested.

Cultivar trial 3. Significant differences $(P<0.0001)$ in PMTVinduced tuber necrosis incidence and severity were found among cultivars. PMTV tuber necrosis incidence ranged from $1.6 \%$ in Lamoka to $47 \%$ in Nicolet (Table 8). Dakota Crisp and Snowden had incidences of PMTV-induced tuber necrosis not significantly different

Table 7. Mean incidence and severity of Potato mop-top virus (PMTV)induced tuber necrosis in potato cultivars planted in 2011 and 2012 and evaluated twice during storage $(\text { trial } 2)^{\mathrm{z}}$

\begin{tabular}{|c|c|c|c|c|}
\hline \multirow[b]{3}{*}{ Cultivar } & \multicolumn{4}{|c|}{ PMTV tuber necrosis } \\
\hline & \multicolumn{2}{|c|}{2011} & \multicolumn{2}{|c|}{2012} \\
\hline & $\begin{array}{c}\text { Incidence } \\
(\%)\end{array}$ & $\begin{array}{c}\text { Severity } \\
\text { index }\end{array}$ & $\begin{array}{c}\text { Incidence } \\
(\%)\end{array}$ & $\begin{array}{c}\text { Severity } \\
\text { index }\end{array}$ \\
\hline Nicolet & 9.0 & 0.16 & $1.6 \mathrm{hi}$ & $>0.00 * \mathrm{~g}$ \\
\hline Alpine Russet & 8.9 & 0.02 & 8.6 defgh & $0.10 \mathrm{defg}$ \\
\hline Dakota Jewel & 8.3 & 0.16 & $24.3 \mathrm{ab}$ & $0.27 \mathrm{c}$ \\
\hline Yagana & 5.1 & 0.11 & $15.7 \mathrm{~cd}$ & $0.30 \mathrm{bc}$ \\
\hline Kennebec & 3.3 & $>0.00^{*}$ & 10.8 cdefg & $0.03 \mathrm{~g}$ \\
\hline $\begin{array}{r}\text { Dark Red } \\
\text { Norland }\end{array}$ & 3.1 & 0.04 & $25.0 \mathrm{ab}$ & 0.18 cde \\
\hline Puren & 3.0 & 0.07 & $\ldots$ & $\ldots$ \\
\hline Snowden & 2.2 & 0.06 & 13.9 cde & $0.42 \mathrm{ab}$ \\
\hline Viking & 2.1 & 0.18 & 6.3 efghi & 0.08 efg \\
\hline Red Pontiac & 2.0 & 0.08 & 7.5 efghi & $0.17 \mathrm{cdef}$ \\
\hline Yukon Gold & 1.5 & $>0.00^{*}$ & $2.1 \mathrm{hi}$ & $>0.0 * \mathrm{~g}$ \\
\hline Red Norland & 1.4 & 0.06 & 7.0 efghi & $0.03 \mathrm{~g}$ \\
\hline Lamoka & 1.0 & 0.05 & $18.8 \mathrm{bc}$ & $0.49 \mathrm{a}$ \\
\hline Red LaSoda & 0.1 & 0.02 & $12.4 \mathrm{cdef}$ & $0.05 \mathrm{efg}$ \\
\hline Patagonia & 0.1 & 0.12 & & \\
\hline Ivory Crisp & $>0.0^{*}$ & $>0.00 *$ & $1.5 \mathrm{hi}$ & 0.06 efg \\
\hline Ranger Russet & 0.0 & 0.00 & 5.8 efghi & 0.05 efg \\
\hline Bannock Russet & 0.0 & 0.00 & $0.0 \mathrm{i}$ & $0.00 \mathrm{~g}$ \\
\hline Russet Burbank & 0.0 & 0.00 & 4.7 fghi & $0.04 \mathrm{fg}$ \\
\hline Karu & 0.0 & 0.00 & $3.6 \mathrm{ghi}$ & 0.04 efg \\
\hline Umatilla Russet & 0.0 & 0.00 & $0.5 \mathrm{hi}$ & $0.02 \mathrm{~g}$ \\
\hline Russet Norkotah & 0.0 & 0.00 & $0.9 \mathrm{hi}$ & $0.00 * \mathrm{~g}$ \\
\hline Shepody & 0.0 & 0.00 & $3.6 \mathrm{ghi}$ & $0.06 \mathrm{efg}$ \\
\hline $\begin{array}{l}\text { Dakota } \\
\text { Trailblazer }\end{array}$ & 0.0 & 0.00 & $0.8 \mathrm{hi}$ & $0.00 * \mathrm{~g}$ \\
\hline Dakota Crisp & $\ldots$ & $\ldots$ & $29.9 \mathrm{a}$ & $0.23 \mathrm{~cd}$ \\
\hline Dakota Pearl & $\ldots$ & $\ldots$ & 11.5 cdefg & $0.11 \mathrm{defg}$ \\
\hline Colorado Rose & $\ldots$ & $\ldots$ & 7.0 efghi & $0.01 \mathrm{~g}$ \\
\hline Alturas & $\ldots$ & $\ldots$ & $4.9 \mathrm{fghi}$ & 0.06 efg \\
\hline Atlantic & $\ldots$ & $\ldots$ & 4.4 fghi & $0.02 \mathrm{~g}$ \\
\hline $\operatorname{LSD}_{(P=0.05)}$ & NS & NS & 8.4 & 0.14 \\
\hline
\end{tabular}

z Means with the same letter are not significantly different based on Fisher's protected least significant difference (LSD) $(P=0.05)$. Index is given as a value between 0 and 1 , where 0 indicates no tuber necrosis and 1 presence of necrosis through the tuber. An asterisk (*) indicates that incidence or severity of PMTV-induced tuber necrosis is not a true zero because there were a few tubers with internal necrosis. NS $=$ no significance. from that of Nicolet. The severity of PMTV-induced necrosis ranged from 0.007 in Lamoka to 0.66 in Nicolet. A very strong positive correlation $(r=0.98, P=0.001)$ was found between PMTV-induced tuber necrosis incidence and severity. Changes in PMTV-induced tuber necrosis incidence $(P>0.98)$ and severity $(P>0.99)$ during storage were not statistically significant. PMTV was confirmed in randomly selected symptomatic tubers by RT-PCR but none tested positive for TRV.

Comparison between PMTV-induced tuber necrosis sensitivity trials. A significant correlation was found between trials 1 and 2 in 2011 for PMTV-induced tuber necrosis severity $(r=0.60, P=$ $0.02)$ but not incidence $(r=0.09, P=0.20)$ using the data from the 14 potato cultivars common between the two trials. However, highly significant and strong correlations were observed in incidence $(r=$ $0.89, P=0.001)$ and severity $(r=0.76, P=0.001)$ between trials 1 and 2 in 2012. Overall, PMTV-induced tuber necrosis incidence and severity in trial 1 were significantly correlated with those parameters in trial 2 across years ( $r=0.69$ and $P=0.01$, respectively).

Relationship between powdery scab infection and PMTVinduced tuber necrosis. In trial 1 , root gall number was significantly correlated with powdery scab incidence $(r=0.51, P=0.05)$ but not severity $(r=0.41, P=0.20)$ on tubers. There was no correlation between root gall number and PMTV-induced tuber necrosis incidence $(r=0.45, P=0.20)$ or severity $(r=0.16, P=0.20)$. A significant correlation $(r=0.62, P=0.02)$ was found between powdery scab incidence on tubers and PMTV-induced tuber necrosis incidence across years. However, there was no correlation $(r=0.14, P=0.20)$ between powdery scab severity on tubers and PMTV-induced tuber necrosis severity across years.

In trial 2, root gall number was significantly correlated with incidence $(r=0.76, P=0.01)$ and severity $(r=0.81, P=0.001)$ of powdery scab on tubers. Root gall number was also significantly correlated with PMTV-induced tuber necrosis incidence $(r=0.54$, $P=0.05)$ but not severity $(r=0.45, P=0.20)$. There was no correlation between powdery scab incidence and PMTV-induced tuber necrosis incidence $(r=0.48, P=0.10)$ or severity $(r=0.17, P=0.20)$ across years.

\section{Discussion}

This is the first study evaluating potato cultivars for sensitivity to PMTV-induced tuber necrosis conducted in the United States or North America, although some North American cultivars were evaluated previously under South American conditions (54). This study was prompted by the increasing importance of PMTV in North America, which poses a serious economic threat to growers. The results obtained in this study demonstrate the existence of a continuum of sensitivity to PMTV-induced tuber necrosis among commonly grown North American potato cultivars from tolerant to sensitive. Therefore, potato growers have the option of replacing cultivars highly sensitive to the development of PMTV-induced tuber

Table 8. Mean incidence and severity of Potato mop-top virus (PMTV)induced tuber necrosis in six white-skinned potato cultivars planted in 2013 and evaluated two times during storage $(\text { trial } 3)^{\mathrm{z}}$

\begin{tabular}{lcc}
\hline & \multicolumn{2}{c}{ PMTV tuber necrosis } \\
\cline { 2 - 3 } Cultivar & Incidence $(\%)$ & Severity index \\
\hline Nicolet & $47.0 \mathrm{a}$ & $0.66 \mathrm{a}$ \\
Snowden & $42.0 \mathrm{a}$ & $0.41 \mathrm{a}$ \\
Dakota Crisp & $36.4 \mathrm{a}$ & $0.41 \mathrm{a}$ \\
Atlantic & $10.0 \mathrm{~b}$ & $0.03 \mathrm{~b}$ \\
Ivory Crisp & $9.4 \mathrm{~b}$ & $0.13 \mathrm{~b}$ \\
Lamoka & $1.6 \mathrm{~b}$ & $>0.00 * \mathrm{~b}$ \\
LSD $_{(0.05)}$ & 10.9 & 0.18 \\
\hline
\end{tabular}

Means with the same letter are not significantly different based on Fisher's protected least significant difference (LSD) $(P=0.05)$. Index is given as a value between 0 and 1 , where 0 indicates no tuber necrosis and 1 presence of necrosis through the tuber. An asterisk (*) indicates that incidence or severity of PMTV-induced tuber necrosis is not a true zero because there were a few tubers with internal necrosis. 
necrosis with tolerant ones in the same market class in production areas where PMTV exists. The identification of cultivars tolerant to PMTV-induced tuber necrosis also provides breeders with useful information for future breeding strategies.

In our study, we made no attempt to ascertain whether the absence of tuber necrosis was due to resistance to PMTV infection or resistance to the expression of tuber necrosis. The results were based on disease response of plants. The occurrence of asymptomatic PMTV infections in tubers has been reported by many researchers $(11,33,49,53)$. The possibility of latent infections occurring means that incidence of PMTV infection among the cultivars could be higher than what has been reported based on tuber necrosis expression. Investigations to reveal the extent of symptomless infection were beyond the scope of this study and are the focus of future research.

The overall significant correlations $(r=0.69, P=0.01)$ in both incidence and severity of PMTV-induced tuber necrosis between trial 1 and trial 2 demonstrate that levels of sensitivity among cultivars in 2011 and 2012 were consistent, an indication of the reliability and reproducibility of the results reported in this study. This evidence demonstrates that field trials can be used to effectively evaluate potato cultivars for sensitivity to PMTV tuber necrosis under North American conditions. The results also show some level of seasonal variation in PMTV tuber necrosis incidence across cultivars even though the ranking of cultivars within a particular season changed very little. Generally, the incidence of PMTV tuber necrosis increased from 2011 through 2013. Due to the low levels of PMTV tuber necrosis incidence observed in 2011, more water was applied via irrigation in 2012 and 2013 than 2011 in order to increase S. subterranea f. sp. subterranea infection. Therefore, the low incidence in 2011 could be due to the low frequency of irrigation applied in late summer, which is the practice among some growers in an attempt to reduce pink rot (caused by Phytophthora erythroseptica Pethybr.) disease pressure. Seasonal variability in PMTV infection among cultivars has also been observed in previous studies $(11,53)$. The occurrence of seasonal variation in PMTV tuber necrosis emphasizes the importance of multiyear assessments for cultivar classification $(40,49)$. Even though the cultivar classification reported in this article is based on the results of trials conducted over two growing seasons, the data offer valuable information upon which future work in this area could be built.

Despite the fact that trial 3 of this study was conducted in only one year (2013), all the cultivars evaluated in this trial were evaluated at least once in trial 2, and the high PMTV tuber necrosis incidence observed in three of the six cultivars tested in trial 3 made its inclusion in this report appropriate. Furthermore, the inclusion of trial 3 offered the opportunity to confirm the high incidence of tuber necrosis observed in Dakota Crisp in 2012 because this cultivar was not evaluated in 2011.

PMTV tuber necrosis incidence (and severity, to some extent) increased more in sensitive cultivars during storage. The most notable exception of a sensitive cultivar which had a large decrease in incidence between the first and second evaluations is Dakota Jewel in trial 2 (2012). A large decrease in PMTV tuber necrosis during storage was recorded in 'Saturna' $(39,40)$, widely regarded to be one of the cultivars most sensitive to tuber necrosis in the Nordic countries $(31,46,49)$. The reasons for the disappearance of tuber necrosis remain unknown but reabsorption of the brown color by the tuber has been implicated (40).

Because PMTV is vectored by $S$. subterranea f. sp. subterranea, susceptibility of cultivars to powdery scab at root and tuber phases was also evaluated. The results demonstrated significant variability in susceptibility to root gall formation (34) and powdery scab on tubers among cultivars. Generally, the russet-skinned cultivars were less susceptible than the red-, white-, and yellow-skinned cultivars to powdery scab infection on tubers (42) but susceptibility to root gall formation did not appear to be associated with skin color. The absence of overall correlation $(r=0.48, P=0.2)$ between incidence of powdery scab on tubers and incidence of PMTV-induced tuber necrosis in trial 2 is consistent with previously published results $(13,30,37,41,47,54)$. However, in trial 1 , the strong overall correlation
( $r=0.62, P=0.02)$ found between incidence of powdery scab on tubers and PMTV tuber necrosis incidence contradict the reports cited above. A study conducted in Scotland to investigate the transmission of PMTV from infected seed tubers to daughter plants found statistically significant correlations $(r=0.48$ and 0.61 in 2004 and 2005, respectively) between the incidence of PMTV and powdery scab for those crops in which both PMTV and powdery scab were present (15). The low or complete absence of correlation between powdery scab on tubers and PMTV infection has been attributed to differences in the optimal environmental conditions required by $S$. subterranea $\mathrm{f}$. sp. subterranea and PMTV $(9,10)$ and the fact that $S$. subterranea $\mathrm{f}$. sp. subterranea infection of other parts of the potato plant such as roots and stolons also causes PMTV transmission $(10,15,28,49)$. However, in the present study, it is likely that the strong correlation between powdery scab on tubers and PMTV-induced tuber necrosis is due to the fact that $50 \%$ of the cultivars evaluated were russet-skinned and not very sensitive to either disease.

The results reported in the present study indicate statistically significant correlations between root gall formation and powdery scab on tubers in trials 1 and 2 as well as PMTV tuber necrosis in trial 2. The strongest correlation occurred between root gall formation and powdery scab incidence and severity $(r=0.76, P=0.01$ and $r=0.81, P=0.001$, respectively) in trial 2 . While the low correlation found between root gall formation and powdery scab as well PMTV tuber necrosis supports the findings of other workers $(9,59)$, the very strong association between powdery scab and root gall numbers in trial 2 contradicts the report of Van de Graaf et al. (59), who noted that the optimum temperature range required for $S$. subterranea f. sp. subterranea infection of roots is higher than the 12 to $15^{\circ} \mathrm{C}$ required for tuber phase infection. The work of Van de Graaf et al. (59) and Carnegie et al. (9) was carried out under constant (controlled) conditions whereas our work was done in the field, where temperature fluctuates day and night during the growing season, and this could explain differences in results.

It is evident from the results that russet-skinned cultivars were the least susceptible to powdery scab lesions on tubers, and this appeared to be associated with low sensitivity to PMTV-induced tuber necrosis. In contrast, many russet-skinned cultivars were susceptible to root gall formation. It is interesting to note that cultivars such as Dakota Crisp, Dakota Jewel, Dark Red Norland, and Red Norland, which were sensitive to both PMTV-induced tuber necrosis and powdery scab infection on tubers, had low levels of $S$. subterranea f. sp. subterranea root infection. These data, therefore, suggest that powdery scab infection on tubers is better linked with and may be more important in leading to PMTV-induced necrosis expression in tubers than the presence of root galls. Here again, we did not investigate symptomless infection by $S$. subterranea f. sp. subterranea on roots or on tubers but this will be the focus of future studies.

In this study, we found that, among the commonly grown potato cultivars in the United States, the russet-skinned cultivars, in comparison with red-, yellow-, and white-skinned cultivars, are not only less susceptible to powdery scab infection on tubers but also are less sensitive to PMTV-induced tuber necrosis. Differences in sensitivity to PMTV-induced tuber necrosis found among cultivars confirms the idea that natural variability exists in North American potato cultivars, which could provide economic relief to potato producers affected by this disease. Potato growers now have the option to plant lesssensitive cultivars in the same market class, especially in areas with a history of S. subterranea f. sp. subterranea and PMTV. Cultivars found to be tolerant to the tuber necrosis phase of PMTV can also be utilized in future breeding programs. The results of this and other studies indicate that soils in parts of the United States are already infested with powdery scab and PMTV in some cases. It is important that a comprehensive survey be conducted to assess the extent of infestation of these two pathogens in the United States. By using harmonized sampling and virus detection procedures, joint PMTV surveys involving 10 countries in Northern Europe were carried out from 2005 to 2008 (49). The experience gained through this project will be useful for planning the surveys in North America. Strict seed surveillance measures need to be put in place to help prevent 
infestation of disease-free soils. In addition, the evaluation of cultivars for sensitivity should be expanded to cover more cultivars and other germplasm, including advanced breeding materials. Furthermore, the extent of latent infections in cultivars should be investigated through techniques such as RT-PCR or ELISA.

\section{Acknowledgments}

We thank I. Mallik, D. Peterson, and R. Benz of the Plant Pathology Department of North Dakota State University for their technical assistance. Portions of this project were funded by the Northern Plains Potato Growers Association and the U.S. Potato Board.

\section{Literature Cited}

1. Andersen, B. A. B., Nicolaisen, M., and Nielsen, S. L. 2002. Alternative hosts for Potato mop-top virus, genus Pomovirus and its vector Spongospora subterranea f. sp. subterranea. Potato Res. 45:37-43.

2. Arif, M., Ali, M., Rehman, A., and Fahim, M. 2014. Detection of Potato mop top virus in soils and potato tubers using bait-plant bioassay, ELISA and RTPCR. J. Virol. Methods 195:221-227.

3. Arif, M., Torrance, L., and Reavy, B. 1994. Improved efficiency of detection of potato mop-top furovirus in potato tubers and in the roots and leaves of soilbait plants. Potato Res. 37:373-381.

4. Arif, M., Torrance, L., and Reavy, B. 1995. Acquisition and transmission of potato mop-top furovirus by a culture of Spongospora subterranea derived from a single cystosorus. Ann. Appl. Biol. 126:493-503.

5. Brunt, A., Crabtree, K., and Gibbs, A. 1990. Viruses of Tropical Plants. $\mathrm{CAB}$ International, Wallingford, UK

6. Calvert, E. L. 1968. The reaction of potato varieties to potato mop-top virus. Rec. Agric. Res. 17:31-40.

7. Calvert, E. L., and Harrison, B. D. 1966. Potato mop-top, a soil borne virus. Plant Pathol. 15:134-139.

8. Carnegie, S. F., Cameron, A. M., and McCreath, M. 2010. Foliar symptoms caused by Potato mop-top virus on potato plants during vegetative propagation in Scotland and their association with tuber yield, spraing and tuber infection. Potato Res. 53:83-93.

9. Carnegie, S. F., Davey, T., and Saddler, G. S. 2010. Effect of temperature on the transmission of Potato mop-top virus from seed tuber and by its vector, Spongospora subterranea. Plant Pathol. 59:22-30.

10. Carnegie, S. F., Davey, T., and Saddler, G. S. 2012. Prevalence and distribution of Potato mop-top virus in Scotland. Plant Pathol. 61:623-31.

11. Carnegie, S. F., Saddler, G. S., and Peters, J. C. 2009. Cultivar susceptibility to Potato mop-top (PMTV) infection and symptom expression. Asp. Appl. Biol. 94:51-54

12. Cooper, J. I., and Harrison, B. D. 1973. Distribution of potato mop-top virus in Scotland in relation to soil and climate. Plant Pathol. 22:73-78.

13. Cooper, J. I., Jones, R. A. C., and Harrison, B. D. 1976. Field and glasshouse experiments on the control of potato mop-top virus. Ann. Appl. Biol. 83: 215-230.

14. Crosslin, J. M. 2011. First report of Potato mop-top virus on potatoes in Washington State. Plant Dis. 95:1483.

15. Davey, T., Carnegie, S. F., Saddler, G. S., and Mitchell, W. J. 2014. The importance of the infected seed tuber and soil inoculum in transmitting Potato mop-top virus to potato plants. Plant Pathol. 63:88-97.

16. David, N., Mallik, I., Crosslin, J. M., and Gudmestad, N. C. 2010. First report of Potato mop-top virus on potatoes in North Dakota. Plant Dis. 94:1506.

17. Epp, M. 2014. Potato mop top virus-Understanding the transmission of an emerging disease. Spudman April 2014:22-23.

18. Falloon, R. E., Viljanen-Rollinson, S. L. H., Coles, G. D., and Poff, J. D. 1995. Disease severity keys for powdery and downy mildews of pea, and powdery scab of potato. N. Z. J. Crop Hortic. 23:31-37.

19. Germundsson, A., Sandgren, M., Barker, H., Savenkov, E. I., and Valkonen, J. P. T. 2002. Initial infection of roots and leaves reveals different resistance phenotypes associated with coat-protein gene-mediated resistance to Potato mop-top virus. J. Gen. Virol. 83:1201-1209.

20. Harrison, B. D. 1974. Potato mop-top virus. CMI/AAB Description of Plant Viruses No. 138. Association of Applied Biologists, Wellesbourne, UK

21. Harrison, B. D., and Jones, R. A. C. 1970. Host range and properties of potato mop-top virus. Ann. Appl. Biol. 65:393-402.

22. Hernandez Maldonado, M. L., Falloon, R. E., Butler, R. C., Conner, A. J., and Bulman, S. R. 2013. Spongospora subterranea root infection assessed in two potato cultivars differing in susceptibility to tuber powdery scab. Plant Pathol. 62:1089-1096.

23. Hu, X., Lei, Y., Xiong, X., He, C., Liu, M., and Nie, X. 2013. Identification of Potato mop-top virus (PMTV) in potatoes in China. Can. J. Plant Pathol. 35:402-406.

24. Imoto, M., Iwaki, M., Tochihara, H., Nakamura, K., and Hanada, K. 1986. Occurrence of potato mop-top virus in Japan and some of its properties. Ann. Phytopathol. Soc. Jpn. 52:752-757.

25. Jones, R. A. C. 1981. The ecology of viruses infecting wild and cultivated potatoes in the Andean region of South America. Pages 89-107 in: Pests, Pathogens and Vegetation: The Role of Weeds and Wild Plants in the Ecology of Crop Pests and Diseases. J. M. Thresh, ed. Pitman Publishing Inc., Marshfield, MA.
26. Jones, R. A. C. 1975. Presence of mop-top virus in Bolivia. Plant Dis. Rep. 59: 193.

27. Jones, R. A. C. 1988. Epidemiology and control of Potato mop-top virus Pages 255-270 in: Developments in Applied Biology II. Viruses with Fungal Vectors. J. I. Cooper and M. J. C. Asher, eds. Association of Applied Biologists, Wellesbourne, UK.

28. Jones, R. A. C., and Harrison, B. D. 1969. The behavior of potato mop-top virus in soil, and evidence for its transmission by Spongospora subterranea (Wallr.). Lagerh. Ann. Appl. Biol. 63:1-17.

29. King, A., Lefkowitz, M. Q., Adams, E., and Carstens, M. J. E. B., eds. 2012 Virus Taxonomy-Ninth Report of the International Committee on Taxonomy of Viruses. Elsevier/Academic Press, London.

30. Kirk, H. G. 2008. Mop-top virus, relationship to its vector. Am. J. Potato Res. 85:261-265.

31. Kurppa, A. 1989. Reaction of potato cultivars to primary and secondary infection by potato mop-top furovirus and strategies for virus detection EPPO Bull. 19:593-598.

32. Lambert, D. H., Levy, L., Mavrodieva, V. A., Johnson, S. B., Babcock, M. J., and Vayda, M. E. 2003. First Report of Potato mop-top virus on Potato from the United States. Plant Dis. 87:872.

33. Latvala-Kilby, S., Aura, J. M., Pupola, N., Hannukkala, A., and Valkonen, J. P. T. 2009. Detection of Potato mop-top virus in potato tubers and sprouts: Combinations of RNA2 and RNA3 variants and incidence of symptomless infections. Phytopathology 99:519-531.

34. Merz, U., Martinez, V., and Schwarzel, R. 2004. The potential for the rapid screening of potato cultivars (Solanum tuberosum) for resistance to powdery scab (Spongospora subterranea) using a laboratory bioassay. Eur. J. Plant Pathol. 110:71-77.

35. Merz, U., Walsh, J. A., Bouchek-Mechiche, K., Oberhansli, T., and Bitterlin, W. 2005. Improved immunological detection of Spongospora subterranea. Eur. J. Plant Pathol. 111:371-379.

36. Millikin, G. A., and Johnson, D. E. 1992. One-way treatment structure in a completely randomized design with heterogeneous errors. Pages 16-28 in: Analysis of Messy Data, Vol. 1. Designed Experiments. Chapman and Hall, London.

37. Montero-Astua, M., Vasquez, V., Turecheck, W. W., Mertz, U., and Rivera, C. 2008. Incidence, distribution, and association of Spongospora subterranea and Potato mop-top virus in Costa Rica. Plant Dis. 92:1171-1176.

38. Nakayama, T., Maoka, T., Hataya, T., Shimizu, M., Fuwa, H., Tsuda, S., and Mori, M. 2010. Diagnosis of Potato mop-top virus in soil using bait plant bioassay and PCR-microplate hybridization. Am. J. Potato Res. 87:218-225.

39. Nielsen, S. L., and Engsbro, B. 1992. Susceptibility of potato cultivars to spraing caused by primary infection of tobacco rattle virus and potato moptop virus. Dan. J. Plant Soil Sci. 96:507-516.

40. Nielsen, S. L., and Molgaard, J. P. 1997. Incidence, appearance and development of potato mop-top furovirus-induced spraing in potato cultivars and the influence on yield, distribution in Denmark and detection of the virus in tubers by ELISA. Potato Res. 40:101-110.

41. Nielsen, S. L., and Nicolaisen, M. 2000. National potato production and the powdery scab situation in Denmark. Pages 67-71 in: Proc. First Eur Powdery Scab Workshop. U. Merz and A. K. Lees, eds. Scottish Agricultural College, Craibstone Estate, Aberdeen, Scotland.

42. Nitzan, N., Cummings, T. F., Johnson, D. A., Miller, J. S., Batchelor, D. L., Olsen, C., Quick, R. A., and Brown, C. R. 2008. Resistance to root galling caused by the powdery scab pathogen Spongospora subterranea in potato. Plant Dis. 92:1643-1649.

43. Robinson, D. J. 1992. Detection of tobacco rattle virus by reverse transcription and polymerase chain reaction. J. Virol. Methods 40:57-66.

44. Ryazantsev, D. Y., and Zavriev, S. K. 2009. An efficient diagnostic method for the identification of potato viral pathogens. Mol. Biol. 43:515-523.

45. Salazar, L. F., and Jones, R. A. C. 1975. Some studies on the distribution of potato mop-top virus in Peru. Am. Potato J. 52:143-150.

46. Sandgren, M. 1995. Potato mop-top virus (PMTV): Distribution in Sweden, development of symptoms during storage and cultivar trials in field and glasshouse. Potato Res. 38:379-389.

47. Sandgren, M., Plaisted, R. L., Watanabe, K. N., Olsson, S., and Valkonen, J. P. T. 2002. Evaluation of some North and South American potato breeding lines for resistance to Potato mop-top virus in Sweden. Am. J. Potato Res. 79:205-210.

48. Sandgren, M., Savenkov, E., and Valkonen, J. P. T. 2001. The readthrough region of Potato mop-top virus coat protein encoding RNA, the second largest RNA of PMTV genome, undergoes structural changes in naturally infected and experimentally inoculated plants. Arch. Virol. 146:467-477.

49. Santala, J., Samuilova, O., Hannukkala, A., Latvala, S., Kortemaa, H., Beuch U., Kvarnheden, A., Persson, P., Topp, K., Ørstad, K., Spetz, C., Nielsen, S. L., Kirk, H. G., Budziszewska, M., Wieczorek, P., Obrępalska-Stęplowska, A., Pospieszny, H., Kryszczuk, A., Sztangret-Wiśniewska, J., Yin, Z., Chrzanowska, M., Zimnoch-Guzowska, E., Jackeviciene, E., Taluntytè, L., Pūpola, N., Mihailova, J., Lielmane, I., Järvekülg, L., Kotkas, K., Rogozina E., Sozonov, A., Tikhonovich, I., Horn, P., Broer, I., Kuusiene, S., Staniulis, J., Uth, J. G., Adam, G., and Valkonen, J. P. T. 2010. Detection, distribution and control of Potato mop-top virus, a soil-borne virus, in northern Europe. Ann. Appl. Biol. 157:163-78. 
50. Savenkov, E. I., Germundsson, A., Zamyatnin, A. A., Sandgren, M., and Valkonen, J. P. T. 2003. Potato mop-top virus: The coat protein-encoding RNA and the gene for cysteine-rich protein are dispensable for systemic virus movement in Nicotiana benthamiana. J. Gen. Virol. 84:1001-1005.

51. Savenkov, E. I., Sandgren, M., and Valkonen, J. P. T. 1999. Complete sequence of RNA 1 and the presence of tRNA-like structures in all RNA's of Potato mop-top virus, genus Pomovirus. J. Gen. Virol. 80:27792784.

52. Scott, K. P., Kashiwazaki, S., Reavy, B., and Harrison, B. D. 1994. The nucleotide sequence of potato mop-top virus RNA 2: A novel type of genome organization for a furovirus. J. Gen. Virol. 75:3561-3568.

53. Sokmen, M. A., Barker, H., and Torrance, L. 1998. Factors affecting the detection of potato mop-top virus in potato tubers and improvement of test procedures for more reliable assays. Ann. Appl. Biol. 133:55-63.

54. Tenorio, J., Franco, Y., Chuquillanqui, C., Owens, R. A., and Salazar, L. F. 2006. Reaction of potato varieties to Potato mop-top virus infection in the Andes. Am. J. Potato Res. 83:423-431.

55. Torrance, L., Cowan, G. H., and Pereira, L. G. 1993. Monoclonal antibodies specific for potato mop-top virus and some properties of the coat protein. Ann. Appl. Biol. 122:311-322.
56. Torrance, L., Cowan, G. H., Sokmen, M. A., and Reavy, B. 1999. A naturally occurring deleted form of RNA 2 of Potato mop-top virus. J. Gen. Virol. 80 2211-2215.

57. Torrance, L., and Mayo, M. A. 1997. Proposed re-classification of furoviruses. Arch. Virol. 142:435-439.

58. Van de Graaf, P., Lees, A. K., Wale, S. J., and Duncan, J. M. 2005. Effect of soil inoculum level and environmental factors on potato powdery scab caused by Spongospora subterranea. Plant Pathol. 54:22-28.

59. Van de Graaf, P., Wale, S. J., and Lees, A. K. 2007. Factors affecting the incidence and severity of Spongospora subterranea infection and galling in potato roots. Plant Pathol. 56:1005-1013.

60. Wale, S. 2000. Summary of the session on national potato production and the powdery scab situation. Pages 3-9 in: Proc. First Eur. Powdery Scab Workshop. U. Merz and A. K. Lees, eds. Scottish Agricultural College, Craibstone Estate, Aberdeen, Scotland.

61. Whitworth, J. L., and Crosslin, J. M. 2013. Detection of Potato mop-top virus (Furovirus) on potato in southeast Idaho. Plant Dis. 97:149.

62. Xu, H., DeHaan, T.-L., and De Boer, S. H. 2004. Detection and confirmation of Potato mop-top virus in potatoes produced in the United States and Canada. Plant Dis. 88:363-367. 